\title{
INDUCTION OF OOCYTE MATURATION IN THE WHITE CROAKER Micropogonias furnieri (PISCES: SCIAENIDAE) BY HUMAN CHORIONIC GONADOTROPIN
}

\author{
GARCÍA-ALONSO, J. and VIZZIANO, D. \\ Oceanología, Facultad de Ciencias, Iguá, 4225, Montevideo, 11400, Uruguay \\ Correspondence to: MsC Javier García-Alonso, Departamento de Fisiología, Facultad de Ciencias, Iguá, 4225, \\ C.P. 11400, Montevideo, Uruguai, e-mail: jgalonso@fcien.edu.uy \\ Received November 6, 2002 - Accepted February 4, 2003 - Distributed February 29, 2004
}

(With 4 figures)

\begin{abstract}
The present work aimed to identify the best doses of human chorionic gonadotropin (hCG) needed to induce oocyte maturation of Micropogonias furnieri and to characterize ovarian dynamics during the periovulatory period. Adult M. furnieri females with fully developed ovaries were injected intraperitoneally with four different doses of hCG. The gonadotropin response was suceeded by analyzing morphologically gonadal biopsies and following the postinjection changes in follicle diameter. Oocyte maturation was induced by three doses used: 100, 300, and $500 \mathrm{IU}$ of hCG kg bw ${ }^{-1}$, and was reached $48 \mathrm{~h}$ after treatment with 300 and $500 \mathrm{IU}$ of hCG kg bw${ }^{-1}$, and $72 \mathrm{~h}$ after treatment with 100 $\mathrm{IU}$ of hCG kg bw${ }^{-1}$. Concerning ovarian dynamics, only 100 and $300 \mathrm{IU}$ of hCG kg bw ${ }^{-1}$ mimicked the natural ones which have a synchronic group maturation. In conclusion, the dose mimicking natural ovarian dynamics and inducing oocyte maturation more quickly is $300 \mathrm{IU}$ of hCG kg bw${ }^{-1}$.
\end{abstract}

Key words: Micropogonias furnieri, fish, reproduction, hormonal induction, oocyte maturation.

\section{RESUMO}

Indução da maturação de oócitos na corvina Micropogonias furnieri (Pisces: Sciaenidae) pela gonadotrofina coriônica humana

O presente estudo teve por objetivo identificar as melhores doses de gonadotrofina cariônica humana (hCG) necessárias para maturação de oócitos de Micropogonias furnieri e caracterizar a dinâmica do ovário ao longo do período pré-ovulatório. Fêmeas adultas de M. furnieri, com ovários completamente desenvolvidos, receberam intraperitonealmente quatro doses diferentes de hCG. A resposta à gonadotrofina foi acompanhada de análise morfológica de biópsias gonadais e mudanças no diâmetro dos folículos após estimulação. A maturação dos oócitos foi induzida por três doses de hCG kg bw ${ }^{-1}, 100,300$ e 500 UI. A maturação dos oócitos foi atingida após $48 \mathrm{~h}$ de tratamento com 300 e $500 \mathrm{UI}$ de hCG kg bw ${ }^{-1}$ e após $72 \mathrm{~h}$ de tratamento com $100 \mathrm{UI}$ de hCG kg bw ${ }^{-1}$. Em relação à dinâmica do ovário, apenas os tratamentos com 100 e 300 UI de hCG kg bw ${ }^{-1}$ reproduziram sua dinâmica natural, apresentando maturação em grupo sincronizada. Esses resultados permitem concluir que a dose capaz de reproduzir a dinâmica do ovário e induzir maturação dos oócitos em curtos períodos é de 300 UI de hCG kg bw ${ }^{-1}$.

Palavras-chave: Micropogonias furnieri, peixe, reprodução, maturação, indução. 


\section{INTRODUCTION}

The white croaker (Micropogonias furnieri, Desmarest, 1823) is a teleost fish widely distributed on the Atlantic coast (Vazzoler, 1998) and important as a fishery resource to Uruguay and Argentina (40.000 ton $\mathrm{yr}^{-1}$ ). Nion (1985) reported that the stock was fully exploited during the 1980s and Arena (1990) confirms that captures have reached the maximum sustainable level for continued exploitation. Recent studies on fishery biology for the white croaker have showed signs of overexploitation (Pin, 1999). Therefore it is important to learn how to control the reproduction of this teleost in captivity in order to develop alternatives for its production by pisciculture. Successful spawning and oocyte maturation were induced by mammalian gonadotropins, particularly by the human chorionic gonadotropin (hCG) on different species (Donaldson \& Hunter, 1983; Donaldson, 1996; Patiño, 1997). In several commercial species of Sciaenidae (Perciforms), hCG was successfully used with to induce oocyte maturation (Thomas, 1994). However, few data are available on hormonal induction of oocyte maturation of $M$. furnieri and it is not known which is the best hormone dose for obtaining optimum maturity response. The objective of this study was to contribute to the understanding of the maturation response process of the female croaker (M. furnieri) kept in captivity and to determine the hCG dose needed to obtain mature gametes.

\section{MATERIAL AND METHODS}

\section{Experimental conditions}

Adult females of white croaker M. furnieri were caught during their spawning season by artisanal fisherman using a gill net on the Montevideo coast (345ㅇ's-5609'W) from October 1996 to March 1997 (Fig. 1). Fish were transferred to 400 1 tanks and maintained at a density of two fishes per tank. As changes in temperature could affect the success of hormonal induction (Harvey \& Hoar, 1979), the water temperature was monitored daily with a multiparameter (YSI, USA). The tank temperatures were kept at around $20.2^{\circ} \mathrm{C} \pm 0.85^{\circ} \mathrm{C}$ during the experimental period.

Salinity and alkalinity of water were also controlled by a multiparameter test (YSI, USA), keeping the first at $30.6 \pm 2.5$ UPS and the $\mathrm{pH}$ at $7.8 \pm 0.2$. Nitrate and ammonia were maintained below toxicological level $\left(<0.1 \mathrm{mg} \mathrm{L}^{-1}\right)$ by using appropriate kits (Wardley Corp).

Fishes were anesthetized using phenoxy-2ethanol (0.40 $\mathrm{ml} \mathrm{L}^{-1}$, Sigma) and weighed before biopsy to determine sex and ovarian maturity stage. Fully-grown females were selected and ovarian samples fixed in a solution of ethanol, formalin, and acetic acid (6:3:1). This fixer also results in a practical clearing solution for sample study (Trant \& Thomas, 1988).

At the end of the experiments, the animals were sacrificed by spinal transection. The gonads were weighed and the gonadosomatic index (GSI) estimated as follows: GSI $=($ gonad weight $/$ total body weight) x 100 (Table 1).

\section{Human chorionic gonadotropin (hCG) treatment}

A single intraperitoneal injection of hCG (PROGON, Dispert, Uruguay) was given to 22 fullygrown females at the following concentrations: 100 $(n=6), 300(n=6), 500(n=7)$, and $750(n=2)$ IU $\mathrm{kg}^{-1}$ of body weight (bw) (Table 1). In our experiments, control females did not mature spontaneously in captivity, as determined by ovarian biopsies.

\section{Evaluation of oocyte maturation}

Two criteria, changes in morphology and diameter, were used to evaluate oocyte maturation progress. Microscopic analysis was made of fixed samples resuspended in glycerol without coloration under light microscopy. Photomicrographs were taken with a Photomicroscope II (Zeiss, Oberkochen) using a photographic Zeiss LUMINAR objective lens (25 mm 1:3.5/A 0.15).

Diameters of 22,950 oocytes were measured with a hemacytometer under a light microscope. Measurements of oocyte diameters $(n=306$ per female) were carried out at $24 \mathrm{~h}$ intervals $(0 \mathrm{~h}, 24$ h, 48 h, and 72 h) during 3 or 4 days after injection. All samples were analyzed after one month of fixation. A shift in oocyte diameter was observed, and a comparison among responses to different doses and times was performed.

\section{Statistical approach}

In order to check the hormonal treatment effect, mean and standard deviation (SD) of fully-grown, maturing, and mature oocytes diameters were estimated. These data were used to judge the maturation process in samples obtained from different females. 
Oocytes with diameters $\geq 400 \mu \mathrm{m}$ were selected as fully-grown, maturing, and mature oocytes. Possible difference of oocyte diameters between control and treated females was tested using the $\chi^{2}$ distribution $(\mathrm{p}<0.01$, Sokal \& Rohlf, 2000) and more advanced oocyte modes were compared to determine the effect of dose and time (analysed by the two way ANOVA test, Statistica 5.0). Different responses to the treatment were evaluated by the Student-Newman-Keuls test $(p<0.05)$. Significant differences were found by the Student test $(p<0.01)$ in the case of $72 \mathrm{~h}$ of exposure.

\section{RESULTS}

\section{Definition of oocyte maturation stages}

Five morphological oocyte stages were recognized after analysis under light microscopy (Fig. 2):

Pre-vitellogenic oocytes (diameter $<50 \mu \mathrm{m}$ ) presented a spherical or polygonal shape. The cytoplasm was translucent with the germinal vesicle (nucleus) located in a central position (Fig. 2A).

Vitellogenic oocytes (diameter 50-400 $\mu \mathrm{m}$ ) exhibited a round shape and an opaque granular cytoplasm. The chorion appeared as a translucent peripheral zone (Fig. 2B, C).

Fully-grown oocytes or postvitellogenic oocytes (diameter of $478 \pm 40 \mu \mathrm{m}$ ) showed a central and opaque germinal vesicle, a granular cytoplasm, and a translucent chorion but thicker than it was at the preceding stage (Fig. 2D).

Maturing oocytes (diameters of $567 \pm 39 \mu \mathrm{m}$ ) presented a migrating germinal vesicle, with a heterogeneous cytoplasm and a coalescent central yolk vesicle (Fig. 2E).

Mature oocytes were characterized by a diameter of $747 \pm 68 \mu \mathrm{m}$, a translucent cytoplasm, germinal vesicle breakdown, and a round yolk vesicle (Fig. 2F).

\section{Mature ovarian stage}

Mature ovarian stage of each female used for the experiments was checked by analyzing ovarian biopsies and by calculating their GSI. The females selected for treatments from 100 to 500 IU of hCG $\mathrm{kg} \mathrm{bw}^{-1}$ showed fully-grown oocytes and high GSI (3\% 4\%). However, females treated with $750 \mathrm{IU}$ of hCG kg bw ${ }^{-1}$ had fully-grown oocytes, but $1.5 \%$ lower GSI (Table 1).

\section{Validation of follicle diameter}

When fully-grown oocytes progressed to mature follicles, changes in oocyte diameter was observed (Table 2) because pelagic eggs of $M$. furnieri exhibit intense and rapid hydration. Fullygrown oocytes presented mean diameters of 478.26 $\mu \mathrm{m}$, while mature oocytes reached $747.3 \mu \mathrm{m}$. Changes in follicular diameters were taken as a good indicator of final oocyte maturation.

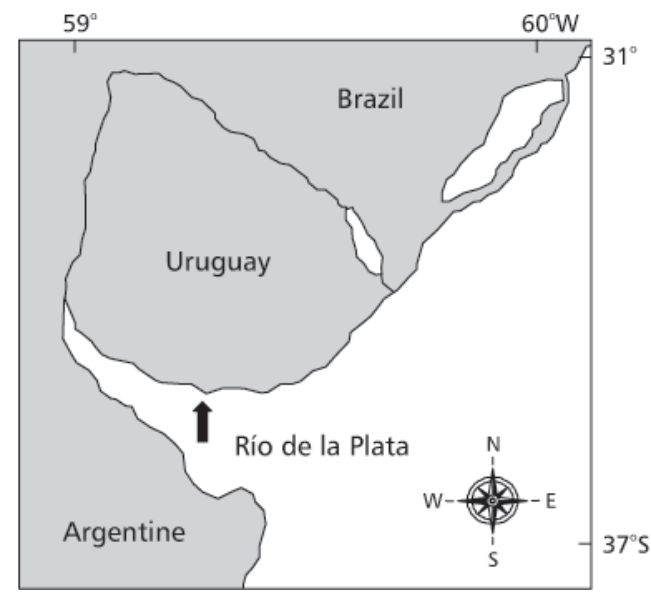

Fig. 1 - Sampling area of white croaker on Montevideo coast (34 $\left.56^{\circ} \mathrm{S}, 56^{\circ} 09^{\prime} \mathrm{W}\right)$ (arrow). 


\section{Hormonal induction of oocyte maturation}

Control fully-grown females do not mature spontaneously in captivity. The oocyte diameter analysis showed no changes after $0,24,48$, and 72 $\mathrm{h}$ indicating the absence of oocyte maturation (Fig. 3 ). When postvitellogenic females were treated with 300 and $500 \mathrm{IU}$ of hCG $\mathrm{kg} \mathrm{bw}^{-1}$, apositive response $(p<0.01)$ was observed in $80 \%$ and $75 \%$ of the cases, respectively (Fig. 3C, D).

Using a lower dose of $100 \mathrm{IU}$ of hCG $\mathrm{kg}$ $\mathrm{bw}^{-1}$, the same level of females $(80 \%)$ reacted positively $(\mathrm{p}<0.01)$ (Fig. $3 \mathrm{~B})$. These females had a high GSI (3 4). However, no reaction was observed when two females were injected with 750 IU of hCG kg bw ${ }^{-1}$.

Oocyte maturation was reached after $48 \mathrm{~h}$ of exposure to doses of 300 and $500 \mathrm{IU}$ of hCG kg $\mathrm{bw}^{-1}(\mathrm{p}<0.05)$, while the same response occurred after $72 \mathrm{~h}$ of exposure $(\mathrm{p}<0.05)$ to $100 \mathrm{IU}$ of hCG $\mathrm{kg} \mathrm{bw}^{-1}$ (Figs. 3B, C, and 4).

In the course of maturation, females treated with 100 and $300 \mathrm{IU}$ of hCG $\mathrm{kg} \mathrm{bw}^{-1}$ showed a similar pattern of oocyte mode response. After stimulation, only one batch of fully-grown oocytes entered the maturation stage, with notably increasing follicular diameters, and finally reached mature diameters. These ovarian dynamics resulted in the presence of one group of non-reactive fully-grown oocytes in the entire time in which they were checked (Fig. 3B, C) and a secondary mode of oocytes whose diameters increased in response to hCG. At the end of the experiment, in both doses the ovaries showed a batch of mature oocytes and a batch of non-reactive fully-grown oocytes (Fig. 3B, C). However, differences between doses affected the time required to reach maturation. When induction was made with $300 \mathrm{UI}$ of hCG kg bw${ }^{-1}$, oocyte diameter differed from those of the control at $24 \mathrm{~h}(\mathrm{p}<0.05)$, and progressed to mature diameters $48 \mathrm{~h}$ after treatment
( $p<0.05$, Fig. 4). In the case of 100 IU of hCG kg $\mathrm{bw}^{-1}$, females showed low response and follicular diameters of reactive oocytes were different from the control only $48 \mathrm{~h}$ after treatment $(\mathrm{p}<0.05)$, reaching mature diameters $72 \mathrm{~h}$ following injection $(\mathrm{p}<0.05$, Fig. 4).

Females treated with $500 \mathrm{IU}$ of hCG kg bw ${ }^{-1}$ showed a different reactive pattern of oocyte maturation than did those with low doses. Massive response of ovaries occurs with a reaction of all fullygrown oocytes (Fig. 3D). At the end of the experiment, although a batch of maturing oocytes and some mature follicles were observed, no non-reactive fully-grown oocytes were (Fig. 3D). Significant differences in oocyte diameters were observed at $24 \mathrm{~h}(\mathrm{p}<0.05)$ and $48 \mathrm{~h}(\mathrm{p}<0.05)$ with respect to the control, resembling what occured with 300 IU of hCG $\mathrm{kg} \mathrm{bw}^{-1}$.

The maturational response of the ovary was also dependent on the hCG dose used, as shown in Fig. 4 by comparing doses of 100, 300, and $500 \mathrm{IU}$ of hCG $\mathrm{kg} \mathrm{bw}^{-1}$ at 24 and $48 \mathrm{~h}$ posttreatment.

\section{DISCUSSION}

Oocyte maturation of M. furnieri was successfully induced by increasing doses of hCG. In our experimental conditions, hCG had a clear and repeatable stimulatory effect when doses of 100, 300, and $500 \mathrm{IU}$ of hCG kg bw${ }^{-1}$ were applied. These results agree with those reported in the literature for other Sciaenidae species such as Micropogonias undulatus in which oocyte maturation was stimulated by doses of hCG from 100 to $500 \mathrm{IU}$ of hCG kg bw (Middaugh \& Yoakum, 1974; Trant \& Thomas, 1989; Patiño \& Thomas, 1990; Thomas et al., 1995), Cynoscion nebulosus by $100 \mathrm{IU}$ of hCG kg bw ${ }^{-1}$ (Thomas \& Trant, 1989), and Sciaenops ocellatus by 500-600 IU of hCG kg bw ${ }^{-1}$ (Colura, 1987).

TABLE 1

Number of white croaker females injected, with different doses of hCG and their gonadosomatic index (GSI).

\begin{tabular}{|c|c|c|}
\hline Females (n) & HCG $\left(\mathbf{k g ~ b w}^{\mathbf{- 1}}\right)$ & GSI \\
\hline 5 & 100 & $4.1 \pm 1.4$ \\
\hline 7 & 300 & $3.1 \pm 0.6$ \\
\hline 8 & 500 & $3.7 \pm 1.6$ \\
\hline 2 & 750 & $1.5 \pm 0.05$ \\
\hline
\end{tabular}



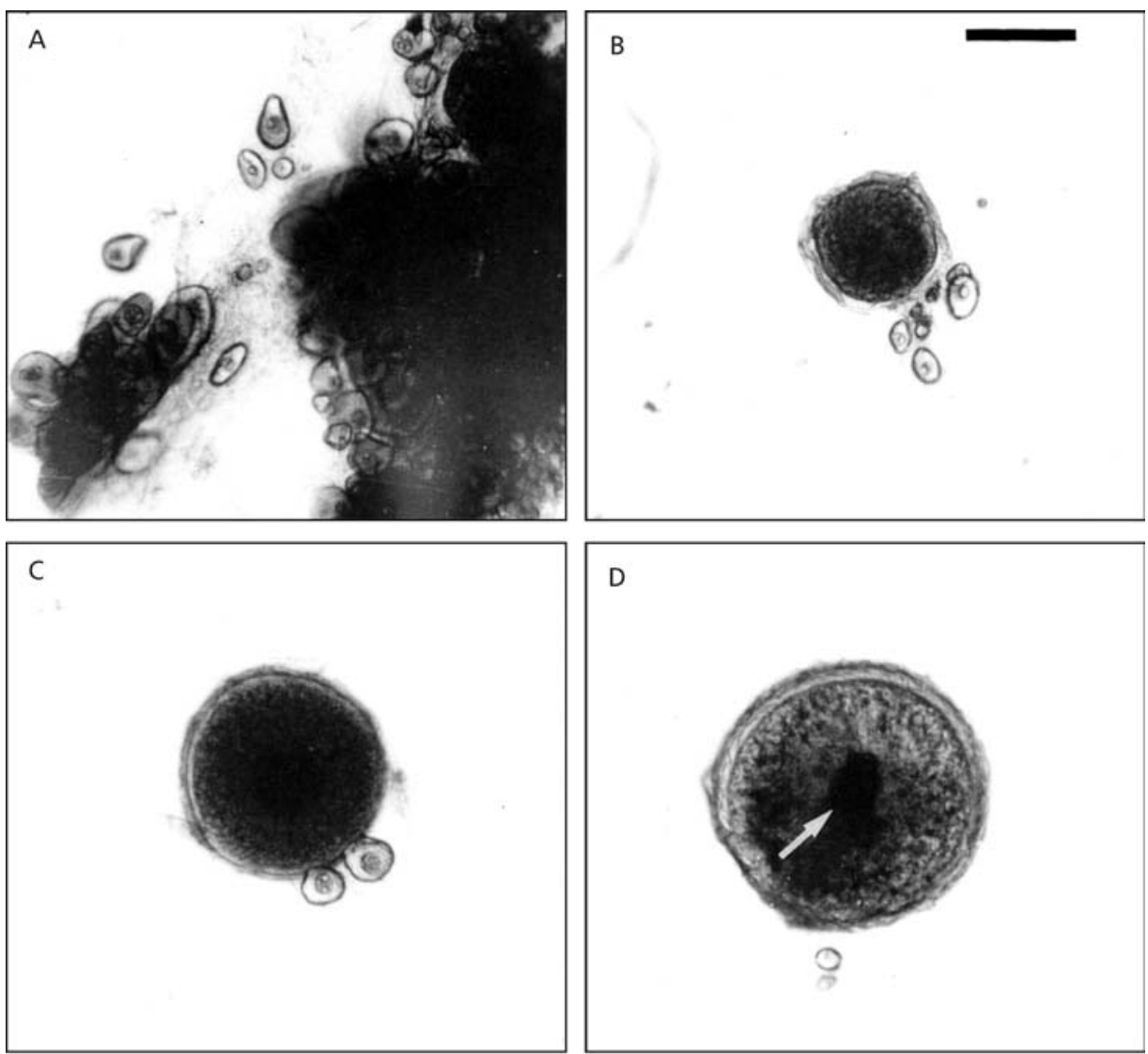

D
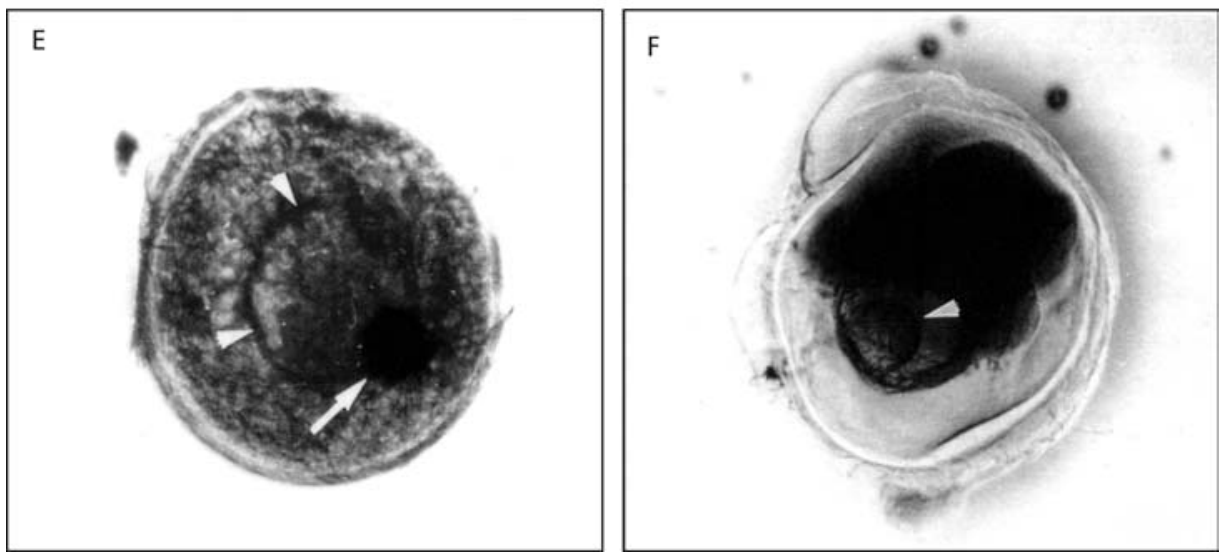

Fig. 2 - Microphotographs of fixed oocytes: A - pre-vitellogenic oocytes; B-C - vitellogenic oocyte; D - fully-grown or postvitellogenic oocyte (arrow indicates the central germinal vesicle position); $\mathbf{E}$ - maturing oocyte with germinal vesicle migration (arrow) and central yolk vesicle in formation (small arrows); $\mathbf{F}$ - mature oocyte, germinal vesicle breakdown, and complete yolk vesicle developed (small arrow). Bar denotes $200 \mu \mathrm{m}$. 
TABLE 2

Oocyte diameter $(>400 \mu \mathrm{m})$ observed at different stages of final oocyte maturation. Information provided by measuring postvitellogenic or fully-grown $(\mathrm{Pv}, \mathrm{n}=3)$, maturing $(\mathrm{Mg}, \mathrm{n}=3)$, and mature $(\mathrm{M}, \mathrm{n}=3)$ females was pooled.

\begin{tabular}{|l|c|c|}
\hline Female stage & $\mathbf{N}$ & Mean oocyte diameter and SD $(\boldsymbol{\mu} \mathbf{m})$ \\
\hline $\mathrm{Pv}$ & 145 & $478.26 \pm 40.34$ \\
\hline $\mathrm{Mg}$ & 118 & $567.18 \pm 39.12$ \\
\hline $\mathrm{M}$ & 106 & $747.33 \pm 68.45$ \\
\hline
\end{tabular}

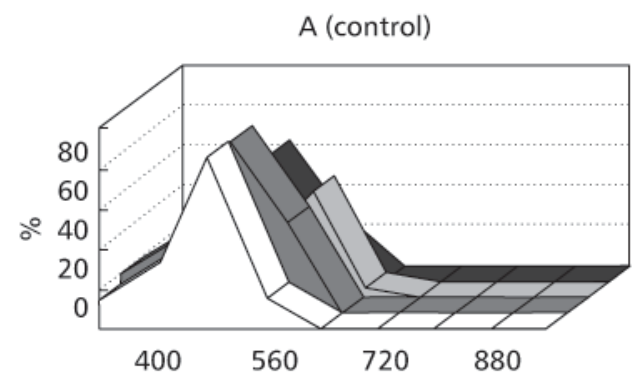

C (300 IU hCG)

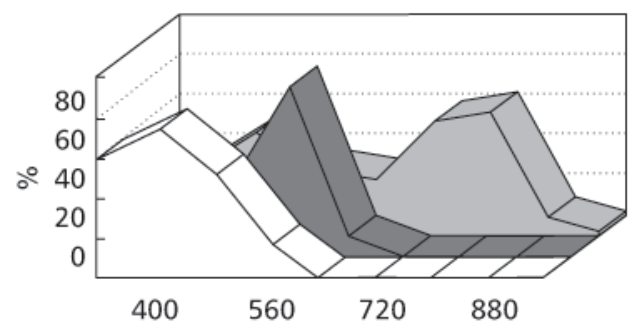

B (100 IU hCG)

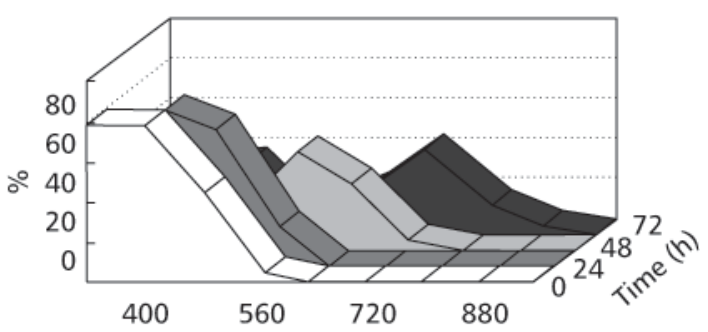

D (500 IU hCG)

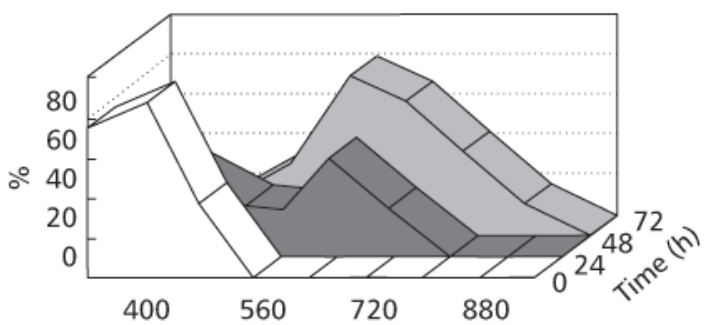

Fig. 3 - Percentage of oocytes observed after treatment with different doses of hCG at different times (only cells from animals that positively reacted to hormone are illustrated): $\mathbf{A}-$ control; $\mathbf{B}-100 \mathrm{IU}$ of hCG kg bw ${ }^{-1} ; \mathbf{C}-300 \mathrm{IU}$ of hCG kg bw ${ }^{-1} ; \mathbf{D}-$ $500 \mathrm{IU}$ of hCG kg bw${ }^{-1}$. Abscissas show oocyte diameters $(\mu \mathrm{m})$.

Injection of hormones has proven to be an effective method of inducing spawning of Sciaenidae, such as orangemouth corvina Cynoscion xanthulus, which do not respond predictably to environmental manipulation (Prentice \& Thomas, 1987; Thomas \& Boyd, 1989).

In the present work, females used for inducing oocyte maturation with 100 to $500 \mathrm{IU}$ of hCG kg $\mathrm{bw}^{-1}$ presented an ovarian stage suitable for reacting positively to the hormone, as showed by their high GSI, corresponding to postvitellogenic and partially spent females. Postvitellogenic oocytes described for M. furnieri with classical histological techniques had a similar diameter $(500 \mu \mathrm{m})$ to that of oocytes observed by us after fixation and observation without tinct (Vizziano et al., 1999). Moreover, a batch of oocytes able to be stimulated by LHRHa in a species close to the orange mouth croaker (Cynoscion xanthulus) had the same diameter (Thomas, 1994). The $M$. furnieri females were caught mainly between December and February during the spawning time of the species (Vizziano, unpublished data). When a higher dose of $750 \mathrm{IU}$ of hCG kg bw${ }^{-1}$ was applied, the females did not react. These females showed 


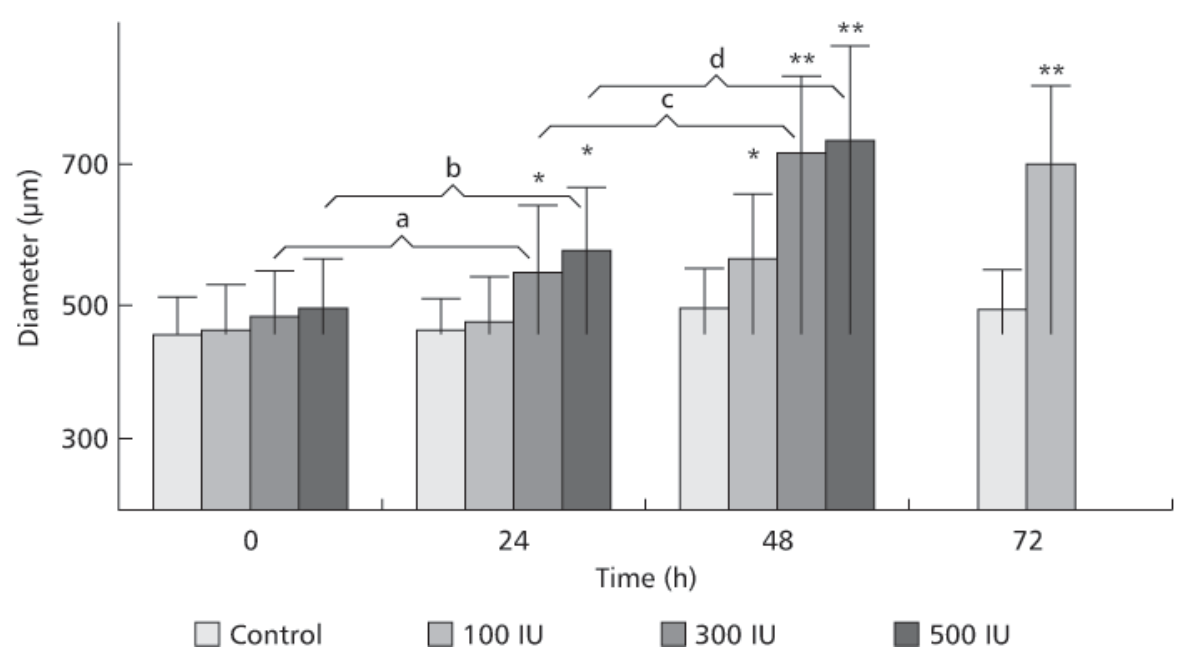

Fig. 4 - Mean and standard deviations of oocyte diameters $(>400 \mu \mathrm{m})$ measured in controls and females that reacted positively with 100,300 , and 500 IU of hCG kg bw ${ }^{-1}$, at $0,24,48$, and $72 \mathrm{~h}$ postinjection. ANOVA (two ways) and Student-NewmanKeuls multiple post-comparison tests were used $(\mathrm{p}<0.05)$. Significant differences were detected by the Student test $(\mathrm{p}<0.01)$ in the case of $72 \mathrm{~h}$. Letters indicate significant differences stimulated by the same dose at different times. The asterisk indicates significant differences between doses for the same time in relation to the control.

a batch of fully-grown oocytes, however they had been caught during March, at the end of the reproductive period, and showed a low GSI (1.5\%) after sacrifice, indicating that the ovary could have been in a regressing phase, like that occurring in other Sciaenid species of the region (Macrodon ancylodon, Vizziano \& Berois, 1990a). Moreover, females at the end of their reproductive season showed a loss of receptivity to gonadotropins (Hodson \& Sullivan, 1993) and probably the batch of oocytes reported as fully-grown were not able to be stimulated by hCG.

Doses of 100 and $300 \mathrm{IU}$ of hCG $\mathrm{kg} \mathrm{bw}^{-1}$ were effective in inducing oocyte maturation in only some fully-grown oocytes at 72 and $48 \mathrm{~h}$ respectively, by mimicking the natural dynamics of the synchronic group ovary maturation of the white croaker.

The strong response obtained by using 500 IU of hCG kg bw ${ }^{-1}$ and thereby inducing massive maturation of fully-grown oocytes does not mimick a natural ovarian dynamics. The same as other members of Sciaenidae family, M. furnieri is a partial spawner in which only a small batch of fully-grown eggs undergoes intense hydration per spawning. In the Sciaenidae fish orangemouth corvina (Cynoscion xanthulus), a similar strong response was observed when $500 \mathrm{IU}$ of hCG $\mathrm{kg} \mathrm{bw}^{-1}$ was used, i.e., considerable swelling of the ovary and subsequent death of fish. Sciaenidae fish seem sensitive to excessive ovarian stimulation by mammalian gonadotropins (Prentice \& Colura, 1984). Since white croaker females were sacrificed after the experiments, the animal mortality rate was not recorded.

Berois (1998), using females and males injected with $750 \mathrm{IU}$ of hCG $\mathrm{kg} \mathrm{bw}^{-1}$, obtained in vitro fertilization and embryos in gastrulae stage. The result of this work will indicate a more adequate dose for inducing maturation in $M$. furnieri. We believe that these kinds of studies may provide interesting tools for the development of successful fish culture that could have results of great commercial importance, particularly for developing countries. Further studies on ovulation rate, hatching rate, and fertilization must be developed to test the viability of gametes obtained under hCG maturation induction.

In conclusion, white croaker ovaries showed a dose-and-time dependent response when stimulated by hCG. The dose of 300 IU mimicked the natural dynamics of this synchronic group partial spawner species and induced oocyte maturation of the species in captivity. 
Acknowledgments - We are very grateful to R. Compte, the fisherman who captured living fish for this work. We thank to N. Berois, D. Carnevia, and A. Carsen for help and advice, and M. E. Drets for critical review of the manuscript. This work was partially supported by PEDECIBA (Uruguay) and IFS (Sweden, A/2340-1) grants.

\section{REFERENCES}

ARENA, G., 1990, Evaluación de la captura máxima sostenible de la corvina blanca (Micropogonias furnieri) presente en el area operativa de la flota uruguaya, mediante modelos de producción excedente. Frente Maritimo, 7(A): 26-35.

BEROIS, N., 1998, Interacciones gaméticas en la corvina blanca, M. furnieri. Características celulares, ultraestructurales y funcionales de los gametos: Gametogénesis y Fecundación. Tesis de Doctorado (PEDECIBA), Universidad de la República, Montevideo, 107p.

COLURA, R. L., 1987, Hormone induced strip-spawning of red drum. Chapter II. In: Manual on red drum Aquaculture. Texas Agricultural Extension Service, College Station, Texas, pp. 7-9.

DONALDSON, E. M. \& HUNTER, G. A., 1983, Induced final maturation, ovulation and spermiation in cultured Fish. In: R. S. Hoar, D. J. Randall \& E. N. Donaldson (eds.), Fish Physiology, Academic Press, 9: 351-403.

DONALDSON, E. M., 1996, Manipulation of reproduction in farmed fish. Animal Reproduction Science, 42: 381-392.

HARVEY, B. J. \& HOAR, W. S., 1979, The theory and practice of induced breeding in fish. IDRC, $48 \mathrm{p}$.

HODSON, R. G. \& SULLIVAN, C. V., 1993, Induced maturation and spawning of domestic and wild striped bass, Morone saxatilis (Walbaum), broodstock with implanted GnRH analogue and injected hCG. Aqua. Fish. Manag., 24: 389398.

MIDDAUGH, D. P. \& YOAKUM, R. L., 1974, The use of chorionic gonadotropin to induce laboratory spawning of the Atlantic Croaker, Micropogonias undulatus, with notes on subsequent embryonic development. Chesapeake Sci. 15: 110-123.

NION, H., 1985, Evaluación y perspectivas del complejo pesquero uruguayo. 2. Análisis de la investigación biológico-pesquera en el Uruguay. CIEDUR. Ser. Invest. Montevideo, 162p.

PATIÑO, R. \& THOMAS, P., 1990, Effects of gonadotropin on ovarian intrafollicular processes during the development of oocyte maturation competence in a teleost, the Atlantic croaker: evidence for two distinct stages of gonadotropin control of final oocyte maturation. Biol. Reprod., 43: 818-827.

PATIÑO, R., 1997, Manipulations of the reproductive system of fishes by means of exogenous chemicals. Prog. Fish Cult., 59: 118-128.
PIN, D., 1999, Estructura poblacional, mortalidad y uso de modelos de producción captura-mortalidad en la pesquería de corvina Micropogonias furnieri (Desmarest, 1823) de la zona común de pesca argentino-uruguaya. Master of Science Thesis. PEDECIBA, Universidad de la República, Uruguay, 104p.

PRENTICE, J. A. \& COLURA, R. L., 1984, Preliminary observations of orangemouth corvina spawn inducement using photoperiod, temperature and salinity cycles. $J$. World Maric. Soc., 15: 162-172.

PRENTICE, J. A. \& THOMAS, P., 1987, Successful spawning of orangemouth corvina following injection with des-Gly ${ }^{10}$ [D-Ala ${ }_{6}$ ]-Luteinizing hormone-releasing hormone (1-9) ethylamide and pimozide. Prog. Fish Cult., 49: 66-69.

SOKAL, R. R. \& ROHLF, F. S., 2000, Biometry. Freeman Co., New York, 887p.

THOMAS, P. \& BOYD, N. W., 1989, Dietary administration of an LHRH analogue induces spawning of spotted seatrout (Cynoscion nebulosus). Aquaculture, 80: 363-370.

THOMAS, P. \& TRANT, J. M., 1989, Evidence that $17 \alpha, 20 \beta, 21-$ Trihydroxy-4-pregnen-3-one is a maturation inducing steroid in spotted seatrout. Fish Physiol. Biochem., 7: 185-191.

THOMAS, P., 1994, Hormonal control of final oocyte maturation in sciaenid fishes. Perspectives in Comparative Endocrinology. National Research Council of Canada, pp. 619-625.

THOMAS, P., ARNOLD, C. R. \& HOLT, G. J., 1995, Red drum and other sciaenids, In: N. R. Bromage \& R. J. Roberts (eds.), Broodstock management and egg and larval quality. Blackwell Science, pp. 118-137.

TRANT, J. M. \& THOMAS, P., 1988, Structure-activity relationships of steroids in inducing germinal vesicle breakdown of Atlantic croaker oocyte in vitro. Gen. Comp. Endocrinol., 71: 307-317.

TRANT, J. M. \& THOMAS, P., 1989, Isolation of a novel maturation-inducing steroid produced in vitro by ovaries of Atlantic croaker oocytes. Gen. Comp. Endocrinol., 75: 405-412.

VAZZOLER, A. E. A., 1998, Biologia da reproducâo de peixes Teleósteos: Teoría e Práctica. EDUEM, Maringá, Paraná, Brazil, 169p.

VIZZIANO, D. \& BEROIS, N., 1990a, Histología del ovario de Macrodon ancylodon. Ovogénesis. Folículos postovulatorios. Atresia. Rev. Brasil. Biol., 50: 523-536.

VIZZIANO, D. \& BEROIS, N., 1990b, Ciclo histológico del ovario de Macrodon ancylodon (Bloch\& Schneider, 1801) (Teleostei: Sciaenidae). Biol. Pesq., 19: 39-47.

VIZZIANO, D., SAONA, G. \& NAGY, G., 1999, Estudio del ciclo reproductivo de la corvina Micropoogonias furnieri en el área de desove del Río de la Plata. Abstract of the XIV Scientific and Technologic Symposium of Comisión Técnica Mixta del Frente Maritimo. Montevideo, Uruguay, pp. 8-9. 